\title{
8 \\ Rethinking economics in the Asian Century: The market and the state in China
}

Leong $\mathrm{H}$. Liew

\section{Introduction}

A key focus of this book is the importance of intellectual engagement with Asia. Particular emphasis is placed on the new theoretical and practical insights that can be gained by doing so that are relevant to a range of social scientists, regardless of their regional specialisation. In that context, the performance of the Chinese economy in the past 30 years provides a smorgasbord of food for thought (and rethought) about the role of the state in economic development and in the economy more generally. The insights to be gained from examining the Chinese case can be used to reflect on the specificities of the relationship between state and market in other national contexts and the resulting implications for economic theory.

China's post-Mao economic transition has drawn eclectically from economic theory in opening the nation to the market, and has recast the state's role as a selective actor in the marketisation of the economy 'with Chinese characteristics'. The economic results are spectacular. China's purchasing power gross domestic product (GDP) overtook Japan's in 2010 to make China's economy 
the world's second largest after the United States. Assuming steady reform and no major shock, by 2030 the size of China's economy is projected to exceed that of the United States (WB and DRC 2012: 6). ${ }^{1}$ If this is achieved, economic reform will have lifted China from being one of the world's poorest countries to the world's largest economy in roughly 50 years.

The economic reform process has steadily decentralised state administration and eroded the Chinese state's role as central planner with its hand tightly on the economy. The state has not, however, simply retreated to make way for the market. From the start of the economic reform period, the state has played a vital role in strategically steering the nation from a centrally planned to a market economy. The state's role in economic management continues to evolve alongside that of the national economy within a dramatically changing global context. By first 'enhancing' and then 'overriding' the market, the state has contributed significantly to post-Mao economic growth and deserves credit for its role in China's 'economic miracle'. ${ }^{2}$

In this chapter, I examine the role of the state in steering China's post-Mao economic transition, which effectively created conditions for market development and then, with an underlay of the market economy in place, overrode the market to maximise not the usual comparative advantage recognised in neoclassical economics but the economic advantage of the size of China's domestic market and the guarantee that the Chinese Communist Party's monopolistic hold on power would continue. I explain how early post-Mao leaders initially created a constituency for market reform and then proceeded with policies to steer the economy towards a structure compatible with the country's comparative advantage given its relative factor endowments. From the mid-1990s, the state shifted its role to overriding the market in order to build 'national champions' in strategic industries. Here, China began to pursue state-led macroeconomic planning along the lines of the so-called developmental state economic policies that had driven impressive economic growth in Japan and South Korea from the 1960s through the state's strong intervention and extensive regulation and planning.

Yet China's state-led economic development policies mirror those of Japan and South Korea only superficially. Two key differences in particular make the Chinese example sui generis. One is size. China's huge landmass and population make the country that much more difficult to govern. Central authority is fragmented and subnational governments can subvert and undermine central

\footnotetext{
1 Subramanian (2011) claimed that China's economy in 2010 was already almost as large as the US economy.

2 Many analysts and officials have referred to East Asia's post-World War II and China's post-Mao economic development experiences as 'miracles'. See, for example, The World Bank and Development Research Center of the State Council, the People's Republic of China (2012: 3).
} 
government industry policies. Size also, however, confers the advantage of a large internal market that can well support industry policy. The other key difference is political structure. In the absence of competition from other political parties, the Chinese Communist Party (CCP) can play a distinctive politico-economic role in shaping the evolving market economy. Yet, as is inevitable in any market economy, the development of markets has given birth to sources of economic power that influence political power and policy and have a huge bearing on the marketisation process. Interest groups have resources to contest official policies ${ }^{3}$ and political players can compete for the hearts and minds of the polity, as the example of fallen political star Bo Xilai well illustrates. ${ }^{4}$ Hence, sectors of the economy that the party perceives to be strategically significant need to be not only granted favourable treatment but also placed under the control of people who are seen to be at least sympathetic to the party. These factors shape the extent and style of the role of the party/state in China's state-led market reform.

\section{Market-enhancing industry policy}

Many neoclassical economists, though not neoliberals, consider state industry policy to be potentially compatible with market reform. Chinese former World Bank chief economist Justin Yifu Lin ${ }^{5}$ in his New structural economics (Lin 2012), for example, advocates industry policy in developing countries to facilitate economic development. In Lin's perspective, industry policy is appropriate when used to help the private sector to produce according to comparative advantage since industry policy is in this case market enhancing. Lin considers that early post-Mao industry policy was clearly 'comparative advantage following'.

The party/state began China's economic reform with decollectivising the agricultural sector. This did not lead to the immediate freeing of agricultural prices since industry could not afford to pay free-market prices for agricultural inputs while receiving planned prices for outputs. The success of agricultural reform depended on the success of industrial reform, but reforming industry was difficult since introducing the market would create winners and losers, with the latter largely concentrated in the state sector. So, in order to build the

\footnotetext{
3 Interest groups in developing countries often buy their preferred outcomes through bribes.

4 Bo Xilai was removed as party chief of Chongqing in March 2012 and suspended from the Politburo. He was later stripped of all official positions and eventually expelled from the party. On 22 September 2013 , he was found guilty of corruption and sentenced to life imprisonment.

5 Justin Lin was born in Taiwan and was a captain in the Republic of China Army before defecting in 1979 to the People's Republic of China. He is a member of the Standing Committee, Chinese People's Political Consultative Council.
} 
necessary constituency of reformers within the party and the state bureaucracy, China's leaders started to develop the market around the planned economy rather than replacing the planned economy altogether.

This plan guaranteed a fixed size of the economy for state-owned enterprises (SOEs), but made the remainder of the economy contestable. State and non-state enterprises were allowed to compete for the non-plan segment. By retaining the plan and allowing the market to operate around it, the party hoped the economy would benefit from the advantages of the market while the state sector would be cushioned from market forces. The competition that the state sector would be exposed to in the market was restricted to sales of non-plan output and purchases of non-plan inputs. This approach would enlarge the economy without harming the state sector (Chen 1987; CPC 1984). This two-track price system is a Pareto-improving strategy, which, by guaranteeing the interests of both the state sector and the officials who managed it, was able to develop a constituency of party and state officials to support this economic reform (Liew 1995). The objective was to arrange for growth out of the plan (Naughton 1995) by first reducing the relative size of the state sector. Only later when the non-state sector had grown sufficiently large enough to absorb underemployed resources of the state sector would attempts be made to shrink the state sector's absolute size.

China's early industry reforms concentrated on developing township and village enterprises (TVEs) and establishing special export zones (SEZs) with tax incentives and other concessions that would attract foreign investment to promote the country's exports. These early efforts were spectacularly successful. The TVEs helped to absorb much of the underemployed labour in the countryside and the export zones laid the foundation for China's later success as a global export powerhouse.

Over the years, China's export structure has been transformed, with a significant shift from agriculture and soft manufactures like textiles and apparel to hard manufactures like consumer electronics, appliances and computers. By 2010, two-fifths of manufacturing exports from developing countries originated from China (Razeen 2011: 5). Transformation of the export structure has not, however, changed the factor intensity of exports, which remain labour intensive. Growth in China's export of hard manufactures is largely due to growth in the processing trade, with Chinese labour assembling high-technology intermediate inputs (Amiti and Freund 2008). Foreign multinational investors in China dominate this processing trade, accounting for 84 per cent of global exports and imports in the trade (Zhou and Latorre 2013). 
In the decade after China joined the World Trade Organization (WTO) in 2001, its share of imports in major world markets doubled and accounted for more than 20 per cent of manufacturing imports. Imports from China accounted for 30 per cent of manufacturing imports into the European Union, 35 per cent into Japan and 25 per cent into the United States. In the most protected sectors in these countries, China's import penetration is even more spectacular. Its share in these sectors in 2009 was about 50 per cent in the European Union, the United States and Canada, and about 55 per cent in Brazil, more than 60 per cent in South Korea, and more than 70 per cent in Japan (Mattoo and Subramanian 2011: 4). The most protected sectors are those in which these importing countries do not enjoy comparative advantage. Both China and India are relatively well endowed in labour, but it is China that has successfully used this comparative advantage to become a global powerhouse in manufactures. China's advantage is so large in certain manufactures that its General Agreement on Trade in Services (GATS) commitments to reduce government support to these manufactures are even more generous than those committed to by developed countries. China's trade liberalisation focuses on sectors where China enjoys comparative advantage and it has reduced tariff rates significantly. China's average tariff rate has been reduced from 40 per cent in 1985 to less than 10 per cent in 2011, and tariff revenue was only 2.5 per cent of total tax revenue in 2009 (Razeen 2011: 4-9).

At the opposite end from manufactures are services. According to neoliberal economists following Lin's categorisation, China's industry policy in services is comparative-advantage defying. China has ranked second in the world in the value of inward foreign direct investment (FDI) since 2000, with most flowing to the manufacturing sector. The service sector is attracting an ever larger share - by 2010, accounting for more than 40 per cent of total FDI. According to Chinese government estimates, foreign investors have invested more than US $\$ 160$ billion in more than 90,000 foreign-invested enterprises (FIEs) in the service sector (Razeen 2011: 5). No doubt China's large domestic market is a major attraction for the huge increase in FDI in the service sector. The additional pull for this FDI, however, is China's protection of its service sector. Although China has opened its service sector to foreign competition and investment (Chen et al. 2011), the sector is still largely internationally uncompetitive so the state is reluctant to commit to further liberalising services under the GATS (Razeen 2011: 9). A clear example is its support for the finance industry. China favours the Chinese bankcard association's UnionPay bankcard over MasterCard and Visa, and allows it to monopolise domestic renminbi-denominated transactions. MasterCard cannot process credit card transactions in renminbi and the central bank, the People's Bank of China (PBC), has prevented ePay Links from partnering with MasterCard to issue renminbi-settled credit cards (Rabinovitch and Anderlini 2013: 20). 


\section{Strategic industry policy 6}

The strategy to grow out of the plan had outlived its usefulness by the 1990s. 'Enhancing' the market had served its purpose well in providing the essential underlay of economic reform; the nation was now ready for the next stage (Hua et al. 1988). Underemployed resources in the non-state sector were fast diminishing and the SOE sector was becoming a drag on the overall economy. China's leaders now concluded the SOE sector was ready to be reformed (CPC 1993; DRC 1999). Substantial reform of SOEs was begun in the mid-1990s and, by 2004, the number of SOEs had been reduced by almost three-quarters - from 120,000 to 32,000 . Employment in SOEs fell by 28 million, or half of the SOE workforce. In 2007, SOEs employed 18 per cent of the urban workforce compared with 50 per cent in 1995 (Xia et al. 2013: 18).

The CCP described its strategy to reform the SOEs as 'zhua da, fang xiao' ('grasp the big and release the small') (Jiang 1995). Small and medium-sized SOEs were privatised while large firms in key industries were converted into conglomerates styled on Japanese keiretsu or Korean chaebols, in a move to build 'national champions'. Industry policy no longer limited the state to helping the private sector produce according to comparative advantage. The state would now also seek to make Chinese firms globally competitive in state-designated industries where China lacked comparative advantage - that is, industries in which neoliberals deemed China to be uncompetitive. Here the state would override the comparative advantage principle and the market. A key plank of this new policy was to promote indigenous innovation, particularly to help build advantage and offset disadvantage for Chinese ventures in global markets.

In designing and implementing China's new strategic industry policy, Chinese policy advisers consulted many of their current and retired Japanese counterparts (Heilmann and Shih 2013). In 2006, the CCP designated seven industries as 'strategic' - defence, electricity generation and distribution, petroleum and petrochemicals, telecommunications, civil aviation, water transport, and coalwhich the state would control. It also targeted machinery, automobiles, electronics and information technology, construction, steel, base metals and chemicals as 'pillar' industries, over which the state would exercise strong influence. While entry barriers into 'pillar' industries are informal and low compared with the barriers to strategic industries, they are high compared with other non-targeted industries and are designed to accept some private operations but discourage private-sector competition (WB and DRC 2012: 26). In 2012 the state owned 30 of the biggest 42 corporations in China and controlled 85 per cent of assets of the 39 sectors that the state considers to be most important (Kurlantzick 2013). 
Lin (2012) considers national strategic industry policies to be 'comparativeadvantage defying': industries that the state chooses to develop are advanced beyond the country's level of economic development or are otherwise beyond what neoclassical economic theory recognises to be the country's comparative advantage. China's strategic industry policy, though, has its own economic logic. The relative factor endowments model of trade (which involves the relative labour force, capital and the available land) behind the free-trade policy prescription favoured by the Washington Consensus ${ }^{7}$ assumes constant returns to scale in production technology (that is, a doubling of inputs will double output) and the presence of competitive markets with many sellers. The relative factor endowment model's evaluation that the economic outcome of state intervention in trade is negative depends very much on these assumptions. Changing these assumptions to better accommodate the realities of China's large domestic market and the oligopolies in the world market can make state intervention in trade economically beneficial.

Krugman (1984) showed that with increasing returns, technology and an oligopolistic market structure, import protection can help make a firm competitive in export markets. Import protection can allow the firm to compete at home, which enables it to realise economies of scale, lower its production costs and hence improve its competitiveness in preparation for entry into the global market. Krugman's and other similar trade models provide a rigorous economic justification for developmental state-type industry policies. The prerequisite is a large domestic market, which enables the domestic firm to initially exploit economies of scale in production from import protection alone, without having to rely on exports right from the start.

Another factor that can justify state intervention in Chinese industry is the nation's great regional variation. To apply economic theory, China is more effectively treated as a country comprising several economies that range from the least developed to the most advanced instead of one homogeneous developing economy. Underdeveloped regions in China that are well endowed with unskilled labour should specialise in low-technology products while developed regions well endowed with skilled labour should specialise in hightechnology products. Hence, short-term state assistance to high-technology industries in China's advanced economic regions could actually be construed in Lin's terminology as following comparative advantage through a marketenhancing industry policy rather than adopting a comparative-advantage defying strategic industry policy.

7 Ramo (2004) labelled China's state-guided development model the 'Beijing consensus'. 
China's strategic industry policy is likely to have a much longer life than the few decades during which Japan, South Korea and Taiwan maintained their strategic industry policies. All three have much smaller populations than China and have successfully carried out strategic industrialisation. The pinnacle of their success, though, was during the Cold War when the United States helped what it saw as its strategically important allies to industrialise through accepting their trade subsidies. The United States kept its domestic market open to their subsidised exports and acquiesced to their protection of domestic industries. The United States no longer sees strategic need to help these three trading partners economically and sees them more as economic competitors even though they are still strategic partners.

Today, strategic industry policy and even market-enhancing industry policy are highly contentious. The global economy is weak and in the European Union, United States and other industrialised countries where unemployment has become a recognised problem, the prospect of further job losses fuels domestic opposition to imports from competitive emerging economies that displace local industrial production. China is the most competitive emerging economy in many sectors. Its large domestic market confers advantages in international bargaining over market access and makes the nation less vulnerable to trade retaliation against its exports when it uses import barriers and export subsidies to exploit economies of scale in domestic production. China is not the first country to exploit its market size in trade conflicts. The White House in 2004 lifted trade restrictions against steel imports into the United States from the European Union - a move taken not because of a WTO ruling but because the European Union had threatened to impose restrictions on imports from the United States, which would have harmed states where President George W. Bush was vulnerable politically. A similar threat from a trading partner with a small domestic market would have carried no weight.

China's huge market size clearly also empowers it to use the principle of divide and conquer in accessing overseas markets. A recent example is the lack of a uniform EU voice on how to deal with China in trade disagreements over China's exports of solar panels and telecommunications products. The EU Trade Commission has accused China of dumping solar panels on the European market, but member countries are split over EU Trade Commissioner Karel de Gucht's plan to impose an import tariff of 47 per cent on solar panels from China. France and Italy support the plan but Germany, Britain, Sweden and the Netherlands oppose it. In a similar vein were the European Union's divided responses to Chinese telecommunications giants Huawei and ZTE. Some European manufacturers were alarmed by cheaper Chinese telecommunications equipment gaining EU market share. Those manufacturers, however, faced opposition from other large European manufacturers such as Ericsson, Alcatel-Lucent SA and Nokia 
Siemens Networks, which fear that Chinese retaliation in response to attempts to control the import of Chinese goods will bring a loss of their own lucrative markets in China (Reuters 2013).

Opinions on how to deal with China's trade strategy are also divided in the United States, where labour favours sanctions against China's 'unfair' trade practices but business is ambivalent or split. Some US firms facing Chinese import competition welcome trade sanctions against China, but US firms exporting from China benefit from China's trade policies, and there are others who fear Chinese government retaliation (Subramanian 2013: 14).

\section{The state and the disadvantage of bigness}

Throughout China's long history, physical size and a large population have enabled subnational (provincial and local) governments to enjoy a large degree of autonomy from the central government. ${ }^{8}$ This has posed enormous challenges to national governance. China's central government has generally found it difficult to enforce national policies at the local level without the cooperation of subnational governments. Post Mao, Beijing finds that implementing its liberal market reforms and strategic industry policies requires active cooperation from subnational governments, but local economic interests activated by these market reforms often lead subnational governments to oppose or moderate national policies.

Localities in the People's Republic of China (PRC) enjoyed a fair amount of autonomy even at the height of central planning when there was continuous tension between the centre and subnational governments. Conflicts between the national and subnational levels, especially over public finance, have a long history that predates the PRC. The centre's historical dependence on the tax collection efforts of subnational governments made rich provinces powerful political actors long before the PRC was created and this has continued to empower them in the current political system (Zhong 2003). The political influence of provinces is formalised in the system, with 'province' a rank in the national political administrative hierarchy equal to a national ministry, andalthough not stated formally - richer provinces and their representatives rank higher than their poorer counterparts.

8 The subnational government hierarchy advances through township, county, prefecture or municipality, and province. Important municipalities such as Beijing and Shanghai have provincial status. Each level is responsible for overseeing the work carried out by lower levels and has two important officials. The one representing the $\mathrm{CCP}$, the party secretary responsible for national policy implementation, is always administratively above the other, who heads the local People's Government. 
Especially since reforms were begun post Mao, subnational governments have utilised their considerable autonomy to become major economic players. They are commonly shareholders in local industrialisation, promoting the development of various industries - from those involved in producing consumer durables to those involved in high-technology production such as civil aviation manufacturing. Local industrialisation efforts are not just to establish globally competitive industries. Subnational governments also promote local industrialisation to create local employment and to maximise local tax revenues. In promoting local economic interests, subnational governments even erected their own regional trade barriers against products made in other localities (Shen and Dai 1990). The disposition of China's powerful provinces towards strategic industry policies and the quest by subnational governments to create local employment and raise local tax revenues have led many specialists to argue that subnational governments and local economic interests, not the central government, are the major impediments to China's WTO compliance (Johnston 2003: 15).

China's strategic industry policy has the powerful backing of national and subnational governments, but there is no guarantee that it will be able to duplicate the success of the post-World War II state-led industry policies of Japan, South Korea and Taiwan. The investigation by Haley and Haley (2013) into state subsidies of Chinese industry identified some dysfunctions that cast doubt on the policy's likely success. Haley and Haley found that competition among subnational governments has led to the expansion of some industries, such as paper and paper products, which have little or no chance of ever becoming competitive. Where there is the prospect of success, as in industries such as automobiles and automobile parts, subnational competition has served to fragment industry and prevent the full exploitation of economies of scale (Haley and Haley 2013: 96-150).

In recent years land-related taxes have been an important source of local revenue. According to Liu (2010: 2), 80 to 90 per cent of local government infrastructure financing comes from land leasing and bank loans with collateral that depends on land and property valuations. Local governments therefore have an interest in high land and property prices and are reluctant to control (on the contrary, they encourage) over-investment in real estate. Local governments in principle are not allowed to run budget deficits. The central government has, however, allowed them to set up local government financing vehicles (LGFVs), which require minimum set-up capital, in order to raise funds from banks for local investment. Many of these investments are - against the wishes of the central government - speculative. There are concerns that many local governments will end up with large hidden deficits (Feng 2010). 
Local officials have a built-in incentive to maximise the funds available for their personal benefit by maximising local fiscal profit - that is, fiscal revenue minus expenditure on local services. The desire to maximise local fiscal profit encourages local speculative investments that promise quick short-term returns. As a result of the CCP's preference for social management over political reform, the quality of local governance is often weak (Fewsmith 2013). Although China has a huge floating labour population, in the countryside households are still largely tied to their land because of the poor functioning of the rural land market. This severely restricts individuals' choice to vote with their feet to discipline local officials for poor performance (Gordon and Li 2011).

\section{The party/state will always be with us}

When the CCP abandoned central planning post Mao, its adoption of a more liberal approach to managing the national economy caused an inherent ideological contradiction with communist orthodoxy. The CCP remains in power as a monopolistic party, but it has had to reinvent itself to do so. This reinvention has meant changing the 'body and soul' of the party. In practice, this involves changing the characteristics of party members ('body'), especially party elites, and redefining party ideology ('soul').

Former CCP general-secretary Jiang Zemin, in his report to the Sixteenth Party Congress in 2002, invoked the notion that whether a person is politically advanced (xianjin) or backward (luohou) does not depend on whether or how much personal property the person owns. A person's political thinking depends on his or her 'biaoxian' (compliant and supportive behaviour towards the party), how they have acquired and how they use any property they may have, and their contribution to building socialism with Chinese characteristics (Jiang 2002: 15). Thus, the CCP does not have to be led by the working class, which paves the way for the party to change its 'body'.

The CCP changes its 'body' in two ways. The first is through the reinvention of party elites. Many members of the elite remake themselves into technocrats and entrepreneurs in the service of market reform in order to remain relevant to the party and to maintain their power and influence within it. Second, the party accepts a new category of elite members who are brought into the CCP from 'advanced elements of other social strata' to prevent the creation of power centres external to the party.

The CCP so far appears to be able to reinvent itself successfully by reconfiguring its support base through co-opting the new social strata empowered by market reform. The party is keen to co-opt the growing elite of skilled professionals, 
managers and private entrepreneurs. Their bargaining power vis-a-vis the party/state has continued to strengthen while marketisation gives them wealth, leverage and space to pursue their interests within a political marketplace. Perhaps nothing better illustrates how far the CCP has reinvented itself than the attendance of seven of China's richest business leaders at the Eighteenth Party Congress in November 2012 to elect China's leaders for the next five years. Those present included Wanda Group boss Wang Jianlin, who has an estimated fortune of US\$10 billion, construction equipment maker Liang Wengen (US\$7.3 billion) and clothing mogul Zhou Haijiang (US\$1.3 billion). A Wall Street Journal report claimed that 160 of China's 1,024 richest people with a total family net worth of US\$221 billion were members of the Party Congress, parliament and the Chinese People's Political Consultative Council (Areddy and Grimaldi 2012).

Reinvention has not only been crucial for enabling the CCP to remain in power as a monopolistic party; it also ensures that China's market reforms will not lead to completely free markets. A monopolistic party will not allow freemarket competition primarily because such competition serves to erode the monopolistic party's continued control of the economy's financial resources, which is essential if the party is to preserve its monopoly on political power. Allowing competitors the use of a level playing field runs counter to the CCP's imperative to secure control over the country's financial resources lest other groups external to the party obtain significant independent sources of finance that can provide them with the capability to pose a serious challenge to the party's monopoly on power. This imperative explains the cautious response among China analysts to Premier Li Keqiang's May 2013 speech in which he announced plans to reduce the state's role in the economy (Barboza and Buckley 2013; Li 2013). Their caution proved to be judicious, as Chinese political leaders at the Third Plenum of the Eighteenth Party Congress in November 2013 reaffirmed 'the leading role of the state-owned economy' (CPC 2013).

\section{The state and resource security}

China's demand for resources has been commensurate with the growth of the national economy. China has designated energy-related industries as strategic, so it is not surprising that its political leaders have not entrusted resource security to the market. China is now the world's largest oil importer, and in 2011 alone it invested US\$12 billion in oil and gas fields all over the world (Arango and Krauss 2013). China's SOEs have invested heavily in Africa to secure supplies of energy and minerals, including in Gabon (iron ore), Guinea (bauxite, diamonds, iron ore, uranium), Zambia (copper) and Angola, Sudan and Nigeria (oil) (Doriye 2010: 26). 
Oil-rich African countries have become strategically important to China. In 2008 Angola displaced Saudi Arabia as the biggest supplier of oil to China, supplying 18 per cent of China's oil consumption (Faucon and Swartz 2009: A4). In Iraq, Chinese SOEs have offered generous terms to secure half of Iraq's oil production-1.5 million barrels a day (Arango and Krauss 2013). Besides generous terms of purchase, China also provides loans to resource-rich developing countries in its quest for resource security. In both 2009 and 2010, the value of loans to developing countries from China exceeded loans from the World Bank (Kurlantzick 2013).

China has also been actively investing in farmland in Africa to improve its own food security. Much farmland in China has been converted to industrial use and policymakers have regarded this and climate change as threatening the nation's food security. Lobell et al. (2011) estimated that climate change alone could potentially increase global food prices by 6.4 to 19 per cent. China is a large food producer and any loss of farmland could impact significantly on world food supply and prices. China's investment in African farmland mirrors its investment strategy in energy and minerals, where China's SOEs, with funding from state banks such as Exim Bank and China Development Bank, negotiated deals with their FDI hosts (Doriye 2010: 29). In February 2009, Chinese state-owned commercial banks had also concluded deals worth more than US $\$ 40$ billion with state oil firms in Brazil, Iran, Russia and Venezuela (Drezner 2009: 43).

China's SOEs, encouraged by the nation's Tenth Five-Year Plan's 'going outside' strategy (Zhu 2001), are active in securing China's resource security, but according to Lieberthal and Wang (2012: 36), these SOEs and other, nonresource-related SOEs act largely independently of one another and commercial considerations drive their decisions. They often compete with one another and their operations are not based on a grand strategy formulated by China Inc., although SOEs, especially those that are resource-related, obtain favourable treatment from state banks.

\section{Getting the state out of the way}

China's industry policies that follow or defy comparative advantage can sometimes convey an impression that the country is governed by an omnipresent, overbearing Chinese state. In reality, China's state authority is fragmented, as mentioned above, and is often deliberately decentralised. China does not, for example, have a uniform minimum wage standard. Provincial and lower-level governments are free to set minimum wages appropriate for their locality. It was only in 2002 that provincial and municipal governments extended the minimum wage to domestic migrant workers (Lam 2006: 97). The Twelfth Five-Year Plan, 
released in 2011, set the ambitious goal of increasing minimum wages by at least 13 per cent a year so that by 2015 the average minimum wage across the nation would be 40 per cent of the average wage (NPC 2011). Achieving this goal will depend on the strength of local economies and the quality of local governance, with less spent on local services meaning more personal benefits for local officials.

Real average wages in China increased more than 200 per cent in the 10 years to 2010. At the height of the impact of the global financial crisis on Asia in 2008 and 2009, Asia excluding China recorded two consecutive years of negative real wage growth, of 2 and 0.9 per cent. Asia with China included, however, posted positive real wage growth of 3.9 and 5.9 per cent (ILO 2013: 20). Despite Chinese workers enjoying significant growth in real wages, such growth still lags behind productivity growth (Schellekens 2013: 2).

There is much official discussion on increasing domestic consumption by rebalancing the economy away from investment, but the state has not actively intervened in the labour market to influence wage outcomes. Wages in China are determined in practice by a largely unregulated labour market. The state regulates the labour market on paper, but enforcement is a different matter. China levies a social insurance contribution charge on employed workers equivalent to an average implicit employment tax of 45 per cent of the wage rate, which is high by international standards. As a result of this levy on employers, however, many of those in the competitive private sector avoid formal employment contracts (WB and DRC 2012: 33).

Workers, on the whole, have not been able to extract a larger share of the gains from the increase in the economy's productivity. The relatively high average wages paid to workers employed by 'national champions' in key industries do not compensate for the low average wages paid to workers in the private sector. The establishment of national champions has worsened wage inequality. National champions are largely immune from private sector competition, earn monopolistic profits and are able to pay premium wages to their workers. Between 1995 and 2002, workers in the state sector enjoyed an annual wage premium 44 per cent above the wage paid to non-state workers. The premium increased to 81 per cent in 2007 (Xia et al. 2013: 18).

Government administration was restructured as well as SOEs. China's government, in the name of reform, shifted a large share of the responsibility for funding services such as health and education from the state to the individual. The result is a fall in government administration employment. By 2011, the fall in employment in SOEs and government administration had reduced public sector employment as a share of the nation's total labour force to 10.2 per cent, which was below that of France (26.7 per cent), Germany (15 per cent) and the 
United States (16.9 per cent) (Rutkowski 2013). Most of the cuts in government services and employment took place in the countryside. In urban China, the state remains a major provider of services and employment. In 2007, the public sector share of urban employment was still 30 per cent (Xia et al. 2013: 18).

In line with neoliberal thinking, China has reduced the direct provision of public services and seeks to aid the poor with direct cash transfers. In 1999 China introduced the Minimum Livelihood Guarantee Scheme (Dibao) under which cash transfers are made to urban poor on a means-tested basis. By 2003 the scheme covered 22 million people, or 6 per cent of the urban population (Ravallion 2009), but it was only introduced nationwide in 2007. To supplement Dibao, local and central governments provide additional cash subsidies to the poor for health, education and housing. Many local governments also provide work support programs. Since Dibao became national, state aid to the poor, especially those living in rural areas, has increased significantly. The increase has not kept up with inflation, though, and can only provide just less than one-quarter of the average level of consumption (Gao 2011). Dibao is a work in progress and it is fair to conclude that after more than three decades post-Mao China has less of a welfare state than most Western democracies. ${ }^{9}$

\section{Conclusion}

The role of the state in China's economy is complex and evolving with the post-Mao economic transition under way. In the early years of reform the state focused industry policy on developing the necessary constituency of reformers in the party/state bureaucracy and pushing ahead with a comparative-advantage following industry policy to develop and expand the market. With market roots established through this policy, the state sought to move beyond this, in pursuit of other sources of economic advantage. It adopted strategic industry policy to take advantage of the economies of scale and scope conferred by China's large geophysical and population size, and through this policy to intervene in the economy to create national champions in the strategic and pillar industries it has selected and protected. The CCP also understands that to maintain its monopolistic political hold it must retain dominant financial power or at least maximise party control over it, which is another imperative to the party/state creating national champions, even though this disables fair market competition in those industries.

9 In a Pew Research Center (2013: 20) study, the proportion of survey respondents in China who considered inequality to be a very big problem (52 per cent) was not much higher than survey respondents who thought so in Germany ( 51 per cent) and the United Kingdom (50 per cent). 
The state is simultaneously disengaging from non-key sectors and getting out of the way of the lives of ordinary people. This has created a highly flexible labour market, but it has also, by implication, forced people to take more responsibility for their personal economic well-being. The state no longer guarantees essential services such as education and health, which it used to provide but has now partially or largely privatised. Meanwhile, the state is actively staying involved in the important role it plays in improving China's resource security since China is a major resource consumer and highly dependent on resource imports.

Market reform at the hand of the party/state has ended suffocation of the private sector by central planning. The end of central planning, however, has not meant the end of state intervention in the economy. The state has disengaged from some areas of the economy but has engaged forcefully in others, and it cannot disengage from the monopolistic CCP. China's position today as an export powerhouse deeply integrated into the global economy attests to the success of China's market reform and economic policies. The achievements of state intervention in China's market reforms are consistent with the research of Rodrik (2013: 28), who showed that the most successful developing economies in the past decade 'have not been the ones with the least state intervention'. State intervention in China, however, is not without political and social costs. The privileged position granted to SOEs in key industries, the fragmentation of industry and state authority, and the focus on social management ahead of political reform have compromised China's otherwise impressive economic achievements, with growing unease among Chinese citizens over ever greater corruption and inequality.

Nevertheless, the distinctive role of the Chinese state in judiciously deregulating and re-regulating the economy in the past three decades clearly has much to offer those who are rethinking economics in the twenty-first century. ${ }^{10}$ With this in mind, the Chinese economy should be studied not just for the lessons it can teach us about China. The Chinese economy should also be studied for the lessons it can teach us about the problematic nature of many of the key assumptions in conventional Western economic thought, particularly regarding the impacts of state activity on the economy.

10 In 2013, with uncertainty over the global economy, people in China responded most optimistically in a Pew international survey (Pew Research Center 2013: 4). In the United Kingdom, only 15 per cent rated the economy as good in 2013 while 69 per cent did so in 2007. The equivalent figures for the United States and Germany are 33 and 50 per cent, and 75 and 63 per cent respectively. But the figures for China are 88 and 82 per cent. Among the Chinese respondents, 80 per cent indicated that they believed their economy would improve in the next 12 months. In the United States, Germany and the United Kingdom, respectively, only 44, 27 and 22 per cent of those polled thought so. 


\section{References}

Amiti, Mary and Freund, Caroline. 2008. The anatomy of China's export growth. Policy Research Working Paper No. 468. Washington, DC: The World Bank.

Arango, Tim and Krauss, Clifford. 2013. China is reaping biggest benefits of Iraq oil boom. The New York Times, 2 June. URL: www.nytimes.com/2013/06/03/ world/middleeast/china-is-reaping-biggest-benefits-of-iraq-oil-boom.html. Consulted 4 June 2013.

Areddy, James T. and Grimaldi, James V. 2012. Defying Mao, rich Chinese crash the communist party. Wall Street Journal, 29 December. URL: wsj.com/ article/SB10001424127887323723104578187360101389762.html. Consulted 13 June 2013.

Barboza, David and Buckley, Chris. 2013. China plans to reduce the state's role in the economy. The New York Times, 24 May. URL: www.nytimes. com/2013/05/25/business/global/beijing-signals-a-shift-on-economic-policy. html?pagewanted=all\&_r=0. Consulted 27 May 2013.

Chen, Qingqing, Goh, Chor-Ching, Sun, Bo and Xu, Lixin Colin. 2011. Market integration in China. Policy Research Working Paper No. 5630. Washington, DC: The World Bank. URL: elibrary.worldbank.org/content/ workingpaper/10.1596/1813-9450-5630. Consulted 4 June 2013.

Chen, Yun. 1987 [1979]. Jihua yu shichang wenti [Issues of plan and market]. In CPC Central Committee Secretariat Research Office and CPC Document Research, eds. Jianchi gaige, kaifa, gaohuo: Shiyijie sanzhong quanhui yilai youguan zhongyao wenxian zhaibian [Persist in reform, opening up, and vitalise: Excerpts of key documents from the Third Plenum of the Eleventh Party Congress]. Reprint. Beijing: Renmin chubanshe.

CPC [Communist Party of China Central Committee]. 1984. China's economic structure reform. Beijing: Foreign Languages Press.

CPC. 1993. Decision of the CPC Central Committee on some issues concerning the establishment of a socialist market economic structure. Beijing Review 22-28 November: 12-31. Original Chinese version in Renmin ribao [People's Daily] 17 November.

CPC. 2013. Zhongguo gongchandang dishibajie zhongyang weiyuanhui disanci quanti huiyi gongbao [Communique of the Third Plenum of the Eighteenth Party Congress of the Communist Party of China]. Beijing: CPC. URL: finance. sina.com.cn/china/20131112/194917300619.shtml. Consulted 13 November. 
Doriye, Elirehema. 2010. The next stage of sovereign wealth investment: China buys Africa. Journal of Financial Regulation and Compliance 18(1): 23-31.

DRC [Development Research Centre of the State Council]. 1999. 1998 nian jingji yunxing de tedian yu chuanzai de wenti [Characteristics and problems of the functioning of the economy in 1998]. Diaocha yanjiu baogao [Investigation and Research Report]. March. Beijing: DRC.

Drezner, Daniel W. 2009. Bad debts: Assessing China's financial influence on great power politics. International Security 34(2): 7-45.

Faucon, Benoit and Swartz, Spencer. 2009. Africa pushes back China on oil search. The Wall Street Journal 30 September: A4.

Feng, Zhe. 2010. Liu Mingkang: zuida fengxian reng jizhong yu difang rongzi pingtai [Liu Mingkang: The greatest risk remains concentrated in local financial platforms]. 2 December. URL: finance.sina.com.cn/ roll/20101220/14359134045.shtml. Consulted 3 June 2011.

Fewsmith, Joseph. 2013. The logic and limits of political reform in China. Cambridge: Cambridge University Press.

Gao, Qin. 2011. Anti-poverty family policies in China: A critical evaluation. Assessing family policies: Confronting family poverty and social exclusion and ensuring work family balance. United Nations Department of Economic and Social Affairs Division for Social Policy and Development Expert Group Meeting, 1-3 June, New York.

Gordon, Roger H. and Li, Wei. 2011. Provincial and local governments in China: Fiscal institutions and government behavior. Working Paper No. 16694. Cambridge, Mass.: National Bureau of Economic Research.

Haley, Usha C.V. and Haley, George T. 2013. Subsidies to Chinese industry: State capitalism, business strategy, and trade policy. Oxford: Oxford University Press.

Heilmann, Sebastian and Shih, Lea. 2013. The rise of industrial policy in China, 1978-2012. Harvard-Yenching Institute Working Paper. Cambridge, MA: Harvard University.

Hua, Sheng, Zhang, Xuejun and Luo, Xiaopeng. 1988. Zhongguo gaige shinian: huigu, fansi he qianjing [Ten years of Chinese economic reform: Review, reflection and prospects]. Jingji yanjiu [Economic Research] December: 1130. 
ILO [International Labour Organisation]. 2013. Global wage report 2012/13: Wages and equitable growth. Geneva: ILO.

Jiang, Zemin. 1995. Zhengque chuli shehui zhuyi xiandaihua jianshe de ruogan da guanxi [The correct handling of several great relationships in the construction of socialist modernisation]. Renmin riabo haiwaiban [People's Daily Overseas Edition] 28 September.

Jiang, Zemin. 2002. Quanmian jianshe xiaokang shehui, kaichuang Zhongguo tese shehuizhuyi shiye xin jumian [Comprehensively build a comfortable well-off society, start a new phase in socialism with Chinese characteristics]. In Zhongguo gongchandang dishiliuci quanguo daibiao dahui wenjian huibian [Compilation of documents from the 16th Party Congress of the Communist Party of China]. Beijing: Renmin chubanshe.

Johnston, Alastair Ian. 2003. Is China a status quo power? International Security 27(4): 5-56.

Krugman, Paul. 1984. Import protection as export protection: International competition in the presence of oligopoly and economies of scale. In Henryk Kierzkowski, ed. Monopolistic competition in international trade. Oxford: Oxford University Press.

Kurlantzick, Joshua. 2013. Why the 'China model' isn't going away. The Atlantic Monthly, 21 March. URL: www.theatlantic.com/china/archive/2013/03/whythe-china-model-isnt-going-away/274237/. Consulted 19 June 2013.

Lam, Willy Wo-Lap. 2006. Chinese politics in the Hu Jintao era: New leadersNew challenges. New York: M.E. Sharpe.

Li, Keqiang. 2013. Zai guowuyuan jigou zhineng zhuanbian dongyuan dianshi dianhua huiyi shang de jianghua [Speech delivered at the teleconference on mobilising to transform the functions of organs of the State Council]. Renmin ribao [People's Daily] 13 May: 2. URL: paper.people.com.cn/rmrb/html/201305/15/nw.D110000renmrb_20130515_1-02.htm. Consulted 16 May 2013.

Lieberthal, Kenneth and Wang, Jisi. 2012. Addressing US-China strategic distrust. Washington, DC: John L. Thornton China Center, Brookings Institution.

Liew, Leong H. 1995. Gradualism in China's economic reform and the role for a strong central state. Journal of Economic Issues 29(3): 883-95.

Liew, Leong H. 2005. China's engagement with neo-liberalism: Path dependency, geography and party self-reinvention. Journal of Development Studies 41(2): 331-52. 
Lin, Justin Yifu. 2012. New structural economics: A framework for rethinking development and policy. Washington, DC: The World Bank.

Liu, Lili. 2010. Strengthening subnational debt financing and managing risks. Review of Economic Research 46(16 August): F-9. Beijing: Ministry of Finance.

Lobell, David B., Schlenker, Wolfram and Costa-Roberts, Justin. 2011. Climate trends and global crop production since 1980. Science May. URL: iis-db. stanford.edu/pubs/23212/Science_5_11.pdf. Consulted 6 May 2011.

Mattoo, Aaditya and Subramanian, Arvind. 2011. China and the world trading system. Policy Research Working Paper No. 5897. Washington, DC: The World Bank.

Naughton, Barry. 1995. Growing out of the plan: Chinese economic reform 19781993. Cambridge: Cambridge University Press.

NPC [National People's Congress]. 2011. Zhonghua Renmin Gongheguo guomin jingji he shehui fazhan dishierge wunian guihua gangyao [People's Republic of China Twelfth Economic and Social Development Five-Year Plan]. Renmin ribao [People's Daily]. URL: politics.people.com.cn/GB/14163461.html. Consulted 12 May 2011.

Pew Research Center. 2013. Economies of emerging markets better rated during difficult times. 23 May. Washington, DC: Pew Research Center. URL: www. pewresearch.org. Consulted 18 June 2013.

Rabinovitch, Simon and Anderlini, Jamil. 2013. China blocks renminbi MasterCard dealings. Australian Financial Review 4 June: 20.

Ramo, Joshua Cooper. 2004. The Beijing consensus. London: The Foreign Policy Centre. URL: www.fpc.org.uk/publications/theBeijingConsensus. Consulted 15 April 2009.

Ravallion, Martin. 2009. How relevant is targeting to the success of the antipoverty program? World Bank Research Observer 24: 205-31.

Razeen, Sally. 2011. Chinese trade policy after (almost) ten years in the WTO: A post-crisis stocktake. Occasional Paper No. 2/2011. Brussels: European Centre for International Political Economy.

Reuters. 2013. EU chief tells China he won't yield on solar panels. Business Spectator, 29 May. URL: www.businessspectator.com.au/news/2013/5/29/ solar-energy/eu-trade-chief-tells-china-he-wont-yield-solar-panels. Consulted 3 June 2013. 
Rodrik, Dani. 2013. The past, present, and future of economic growth. Working Paper No. 1 (June). London: Global Citizen Foundation.

Rutkowski, Ryan. 2013. A shrinking leviathan: State employment in China looms smaller than expected. China Economic Watch 24 January. Washington, DC: Petersen Institute for International Economics.

Schellekens, Philip. 2013. A changing China: Implications for developing countries. Economic Premise No. 118. Washington, DC: The World Bank. URL: documents.worldbank.org/curated/en/2013/05/17747448/changingchina-implications-developing-countries. Consulted 30 May 2013.

Shen, Liren and Dai, Yuanchen. 1990. Wo guo duhou jingji de xingcheng jiqi biduan he genyuan [The duchy economies: Form, origin and negative features]. Jingji yanjiu [Economic Research] March: 12-19.

Subramanian, Arvind. 2011. Eclipse: Living in the shadow of China's economic dominance. Washington, DC: Peterson Institute of International Economics.

Subramanian, Arvind. 2013. Preserving the open global economic system: A strategic blueprint for China and the United States. Policy Brief No. PB1316. Washington, DC: Petersen Institute for International Economics.

WB and DRC [The World Bank and Development Research Center of the State Council, the People's Republic of China]. 2012. China 2030: Building a modern, harmonious, and creative high-income society. Washington, DC: The World Bank.

Xia, Qingjie, Song, Lina, Li, Shi and Appleton, Simon. 2013. The effects of the state sector on wage inequality in urban China: 1988-2007. CGC Discussion Paper No. 19, February. Oxford: China Growth Centre, Oxford University.

Zhong, Yang. 2003. Local government and politics in China: Challenges from below. Armonk, NY: M.E. Sharpe.

Zhou, Jing and Latorre, Maria C. 2013. How FDI influences the triangular trade pattern among China, East Asia and the US. A CGE analysis of the sector of electronics in China. April. West Lafayette, Ind.: GTAP Resource Centre. URL: www.gtap.agecon.purdue.edu/resources/download/6245.pdf. Consulted 4 June 2013.

Zhu, Rongji. 2001. Report on the outline of the Tenth Five-Year Plan for National Economic and Social Development. Delivered at the Fourth Session of the Ninth National People's Congress. 5 March, Beijing. URL: english.gov.cn/ official/2005-07/29/content_18334.htm. Consulted 29 May 2014. 
This text is taken from The Social Sciences in the Asian Century, edited by Carol Johnson, Vera Mackie and Tessa Morris-Suzuki, published 2015 by ANU Press, The Australian National University, Canberra, Australia. 